УДК 658.5.016:336.748.12

Крейдич I. М.

доктор економ.наук, професор

Національний технічний університет Украӥни «КПІ»

Наконечна О. C.

канд. економ.наук

Міжнародний університет фінансів

Харченко О. C.

Національний технічний університет Украйни «КПІ»

\title{
УМОВИ ЗАБЕЗПЕЧЕННЯ ПЛАТОСПРОМОЖНОСТІ ПІДПРИССТВ В КОНТЕКСТІ ЇХ ФІНАНСОВОЇ БЕЗПЕКИ
}

\author{
УСЛОВИЯ ОБЕСПЕЧЕНИЯ ПЛАТЕЖЕСПОСОБНОСТИ ПРЕДПРИЯТИЙ В \\ КОНТЕКСТЕ ИХ ФИНАНСОВОЙ БЕЗОПАСНОСТИ
}

\section{CONDITIONS OF ENTERPRISES SOLVENCY ENSURING IN THE CONTEXT OF FINANCIAL SECURITY}

В статті на основі дослідження теоретичних та методичних базисів фінансового менеджменту щзодо умов забезпечення платоспроможності підприємства як одного із важливих індикаторів фінансової безпеки виробничо-економічної системи виявлено відсутність чіткого та єдиного підходу до градації та класифікаиії зазначених умов. Враховуючи проблематику даного дослідження доведено наявність потреби у виборі оптимальних умов, які мають найбільш значний вплив на прочес забезпечення платоспроможності підприємств та підвищують ефективність фінансово-господарської діяльності суб'єктів господарювання, а також рівень їх фінансової безпеки в сучасних умовах розвитку економіки. Результати дослідження дозволили запропонувати власне бачення основних умов забезпечення платоспроможності підприємства з позииіі фінансової безпеки. Визначено, щзо основними такими умовами для підприємства є: наявність та забезпечення ліквідності активів та задовільної структури балансу; збалансована структура джерел формування капіталу підприємства; ефективне управління дебіторською та кредиторською заборгованістю; рачіональне та збалансоване управління грошовими потоками; вибір та застосування ефективних форм розрахунків. Доведено, шео дотримання вказаних умов забезпечення платоспроможності підприємства дозволить уникнути загрози погіршення рівня його фінансової безпеки.

Ключові слова: платоспроможність, фінансова безпека підприємств, банкрутство, неплатоспроможність, дебіторська та кредиторська заборгованість, грошові потоки, фінансові ресурси, ліквідні активи, ефективні форми розрахунків.

В статье, на основе исследования теоретических и методических базисов финансового менеджмента в отношении условий обеспечения платежеспособности предприятия как одного из важных индикаторов финансовой безопасности производственно-экономической системы, обнаружено отсутствие четкого и единого подхода к градации и классификации указанных условий. Учитывая проблематику данного исследования, доказано наличие потребности в выборе оптимальных условий, которые имеют наиболее значительное влияние на прочесс обеспечения платежеспособности предприятий и повышают эффективность финансово-хозяйственной деятельности 
субъектов хозяйствования, а также уровень их финансовой безопасности в современных условиях развития экономики. Результаты исследования позволили предложить собственное видение основных условий обеспечения платежеспособности предприятия с позиции финансовой безопасности. Определено, что основными такими условиями для предприятия являются: наличие $u$ обеспечение ликвидности активов $u$ удовлетворительной структуры баланса; сбалансированная структура источников формирования капитала предприятия; эффективное управление дебиторской и кредиторской задолженностью; рачиональное и устойчивое управление денежными потоками; выбор и применение эффективных форм расчетов. Доказано, что соблюдение указанных условий обеспечения платежеспособности предприятия позволит избежать угрозы ухудшения уровня его финансовой безопасности.

Ключевые слова: платежеспособность, финансовая безопасность предприятий, банкротство, неплатежеспособность, дебиторская и кредиторская задолженность, денежные потоки, финансовые ресурсы, ликвидные активы, эффективные формы расчетов.

In the article on the basis of financial management theoretical and methodological bases research as for the conditions of enterprise solvency ensuring as one of the important indicators of the economic and production system financial security was revealed the absence of clear and unified approach to the gradation and classification of mentioned conditions. Taking into account the problems of this study it was proved presence of the needs to choose the optimal conditions that have the most significant impact on the process of the enterprise solvency ensuring and improve the efficiency financial and economic activities of entities, and their level of financial security in modern conditions of economic development. Results of the study allowed offering own vision of the basic conditions for the enterprise solvency ensuring from the position of financial security. It was determined that such basic conditions for the enterprise are: availability and provision of assets liquidity and satisfactory balance sheet structure; balanced enterprise capital formation sources structure; effective receivable and payable accounts management; rational and sustainable cash flow management; selecting and applying of effective payment methods. It was proved that compliance with these conditions of enterprise solvency provision will allow avoiding the threat of its financial security level worsening.

Keywords: solvency, financial security, bankruptcy, insolvency, receivables and payables, cash flow, financial resources, liquid assets, effective forms of payment.

Вступ. Сучасний стан розвитку вітчизняних суб’єктів господарювання, які функціонують в умовах невизначеності та під впливом різного роду загроз, ставить перед керівним складом підприємства питання щодо прийняття виважених рішень в сфері забезпечення оптимального рівня фінансової безпеки, постійний моніторинг за яким забезпечує стабільність функціонування та дотримання основних стратегічних цілей підприємства. У зв'язку 3 тим, що одним 3 основних індикаторів фінансової безпеки підприємств $є$ платоспроможність, виникає потреба у визначенні та характеристиці основних умов, які забезпечують здатність до трансформації фінансових ресурсів в готові засоби платежу для підтримки оптимального рівня стійкості розвитку підприємств.

Аналізу умов щодо забезпечення платоспроможності підприємства у сфері реалізації фінансової безпеки приділяли увагу такі вчені як: І. Бланк, 
Ф. Бутинець, В. Галасюк, Ю. Журавльова, А. Поддєрьогін, І. Пономарьов, Д. Солодух, М. Рибченко, Ю. Тютюнник, А. Шеремет та інші.

Постановка завдання. Метою даної статті є дослідження теоретичного та методичного підгрунтя забезпечення платоспроможності підприємств в розрізі їх фінансової безпеки.

Методологія. Теоретико-методологічним базисом роботи є наукові праці вітчизняних та зарубіжних вчених у сфері оцінювання платоспроможності підприємств в системі їх фінансової безпеки. Для досягнення поставленої мети використано загальнонаукові та спеціальні методи дослідження, такі як: системний підхід, методи аналізу та синтезу, прийоми логічного узагальнення.

Результати дослідження. Відомо, що ефективність діяльності будь-якого підприємства насамперед залежить від швидкості та якості здійснення ним розрахунків за своїми зобов'язаннями перед контрагентами. Необхідність підтримки iï на високому рівні в короткостроковій та довгостроковій перспективі забезпечують нормальний ритм фінансово-господарської діяльності підприємства. Враховуючи вищевикладене платоспроможність являє собою складну економічну категорію як у понятійному так і у методичних аспектах.

В результаті дослідження еволюції поглядів щодо сутності категорії «платоспроможність» науковці наводять різні підходи щодо ії трактування.

Перший підхід - системний, полягає в тому, що під платоспроможністю вважають спроможність підприємства виконувати свої зобов'язання в цілому, незважаючи на строки і за рахунок активів, що були сформовані та оцінені на певну дату. В контексті даного погляду, констатують, що фінансова стійкість являється передумовою платоспроможності. Другий підхід короткостроково-орієнтований визначає платоспроможність як можливість підприємства погашати свої термінові та поточні зобов'язання. В даній трактовці вже платоспроможність $є$ передумовою фінансової стійкості.

Залежно від резидентності дослідників виділяють такі підходи як західний, російський та вітчизняний. Відповідно до західного підходу платоспроможність характеризується як здатність суб'єкта господарювання покривати свої збитки та мати в наявності власні оборотні кошти. Саме поняття «збитки» трактується як платежі, що підлягають оплаті або погашенню. Крім того, підприємство повинно мати відповідний резерв, який надавав би можливість в разі отримання ним негативного фінансового результату, покривати вказані збитки [4, с.117].

Російський підхід визначає платоспроможність як здатність підприємства виконувати свої зобов'язання. Така інтерпретація вказує на те, що підприємство в своєму розпорядженні повинно мати відповідну суму грошових коштів, яку воно може спрямувати на погашення свої короткострокових зобов'язань у будь-який момент часу. Постає дискусійне 
питання стосовно того, що суб'єкту господарювання недостатньо погашати лише короткострокову заборгованість, адже значна частина підприємств має і довгострокову заборгованість, яку також необхідно погашати з часом. Тому вже у визначенні А.Д. Шеремета вказано, що платоспроможність необхідно розглядати 3 позиції здатності покривати усі свої зобов'язання (короткострокові та довгострокові) за рахунок загальної вартості активів [6, c.34,15].

Відповідно до вітчизняного підходу платоспроможність представляють як важливий показник фінансової стійкості i взагалі фінансового стану підприємства [12, с.117]. Виходячи 3 такого твердження визначено, що підприємство повинно мати достатній обсяг ліквідних коштів, для погашення необхідних зобов'язань та платежів.

Проведений аналіз підходів щодо трактування поняття «платоспроможність» дає змогу зазначити, що відмінність виділених підходів полягає не тільки в рівні охоплення зобов'язань, але і у взаємозв'язку 3 іншими категоріями такими як фінансова стійкість та ліквідність.

Розглядаючи сутність платоспроможності виникає необхідність у дослідженні основних умов забезпечення платоспроможності як однієї 3 складових фінансової безпеки підприємства.

Під забезпеченням платоспроможності підприємства визначають систему організаційно-економічних заходів, які спрямовані на ефективне управління платоспроможністю підприємства, оперативне виявлення ознак неспроможності виконання обов'язкових платежів у встановлений термін, формування передумов до зниження ризику неплатежів 3 метою нормального функціонування підприємства в результаті здійснення операційної, фінансової та інвестиційної діяльності [5, с.4].

Забезпеченість платоспроможності у часі являє собою процес, який пов'язаний зі зміцненням фінансового стану підприємства, а його стійкість залежить від результатів діяльності виробничо-економічної системи.

Досліджуючи сутність платоспроможності деякі автори визначають ії як спроможність погашати свої зобов'язання, при цьому умовою даної спроможності визначають наявність у підприємства активів, які мають різний рівень ліквідності. Тому логічним $є$ твердження за яким необхідною умовою забезпечення платоспроможності являється наявність та забезпечення ліквідності активів підприємства.

Ліквідність активів трактується як здатність їх трансформуватися в грошові кошти, при цьому ступінь ліквідності визначається як тривалість періоду, протягом якого така трансформація може бути здійснена. Тобто, чим менше необхідно часу для інкасації певного активу, тим вищий його рівень ліквідності. В даному контексті розглядати ліквідність необхідно з позиції 
того, який час необхідно для продажу активів та яка сума буде одержана в результаті такого продажу [13, с.301].

Розкриваючи сутність ліквідності активів варто зупинити свою увагу на ліквідності балансу тому, що дана категорія розкриває ступінь покриття боргових зобов'язань підприємства його платіжними засобами, строк перетворення яких на грошові кошти відповідає строку погашення платіжних зобов'язань. Як відомо в процесі дослідження ліквідності балансу проводять групування за ознакою ліквідності активів та терміновістю оплати пасивів балансу, порівнюють їх величини між собою та формують висновки стосовно характеру їх ліквідності.

Для забезпечення умови платоспроможності підприємства в розрізі ліквідності балансу варто, щоб баланс був абсолютно ліквідним $(A 1 \geq \Pi 1, A 2 \geq$ $\Pi 2, A 3 \geq \Pi 3, A 4 \leq \Pi 4)$ або задовільний, тобто не виконується одна або дві 3 наведених вимог нерівності. Якщо не виконується жодна з умов, баланс $є$ неліквідним, тобто у підприємства не вистачає високоліквідних засобів для погашення термінових зобов'язань, що в свою чергу відобразиться на рівні його фінансової безпеки.

В залежності від того, якими видами оборотних активів підприємство погашає свої зобов'язання виділяють три рівні платоспроможності:

1) грошова платоспроможність, яка характеризується коефіцієнтом абсолютної платоспроможності, що визначає миттєву платоспроможність і вказує на те, яку частину поточних зобов'язань підприємство може погасити негайно високоліквідними оборотними активами. Крім того даний показник $є$ найбільш жорстким критерієм в процесі оцінювання платоспроможності. Нормативне значення даного коефіцієнта повинно бути $\geq 0,2$, яке означає, що підприємство є грошово платоспроможним і високоліквідні оборотні активи покривають поточні зобов'язання не менше ніж на 20\%;

2) розрахункова платоспроможність або коефіцієнт проміжної платоспроможності визначає потенційну платоспроможність підприємства 3 урахуванням майбутніх надходжень від дебіторів. Показник вказує на те, яку частину поточних зобов'язань підприємство може погасити за рахунок високо та середньоліквідних активів. Коефіцієнт дає змогу визначити рівень платоспроможності підприємства за період, який дорівнює середній тривалості одного обороту поточної дебіторської заборгованості за умови повного та своєчасного іiі погашення і значення якого повинно перебувати в діапазоні 0,7-0,8;

3) майнова платоспроможність або коефіцієнт загальної платоспроможності являється комплексним показником оцінювання платоспроможності підприємства, що відображає відношення всієї суми оборотних активів до величини поточних зобов'язань. Даний показник вказує 
на прогнозні платіжні можливості на відносно віддалену перспективу. Теоретичне значення показника становить 1,5-2 [13, с.280].

Важливого значення в контексті дослідження умов забезпечення платоспроможності з точки зору ліквідності коштів набуває наявність у підприємства задовільної структури балансу, визначення якої пов'язано 3 розрахунком двох показників: коефіцієнта загальної ліквідності та коефіцієнта забезпеченості оборотних активів власними оборотними коштами. Вказані показники являються критеріями оцінювання структури балансу підприємства.

Якщо показник загальної ліквідності більше або дорівнює 1,5, а коефіцієнт забезпеченості оборотних активів власними оборотними коштами більше або дорівнює 0,1 така структура балансу являється задовільною, а підприємство - платоспроможним.

В тому разі коли дані критерії не виконуються, це свідчить про незадовільну структури балансу i як наслідок неплатоспроможність підприємства та зниження рівня його фінансової безпеки.

На основі визначених критеріїв структури балансу підприємства сформовано ряд таких рекомендацій: 1) темпи росту оборотних активів повинні бути вищими у порівнянні з темпами росту поточних зобов'язань; 2) збільшення обсягів оборотних активів повинно супроводжуватися одночасним зменшенням на цю саму величину вартості необоротних активів (переведення частини їх в оборотні кошти шляхом застосування методів прискореної амортизації); 3) максимальне обмеження вкладень капіталу у важколіквідні оборотні активи та недопущення вкладень у неліквідні; 4) потребу у збільшенні величини власного капіталу підприємства можливо забезпечити за рахунок зростання нерозподіленого прибутку та статутного капіталу.

В процесі дослідження забезпечення платоспроможності необхідно враховувати особливості та тривалість операційного та фінансового циклів підприємства в розрізі окремих видів діяльності. Важливим $є$ також визначення напрямку зміни активів чи пасивів підприємства таким чином, щоб сума його грошових коштів збільшилась. Чим менша тривалість фінансового циклу, тим менше фінансових ресурсів потрібно для фінансування виробничих потреб підприємства [7].

Отже, наявність та забезпечення ліквідності активів сприяє мінімізації ризику несплати за зобов'язаннями, що в свою чергу підвищує рівень фінансової безпеки підприємства.

Збалансована структура джерел формування капіталу є беззаперечною запорукою забезпечення довгострокової платоспроможності виробничоекономічної системи. Формування достатньої частки власного капіталу у складі джерел фінансування є гарантом постійної можливості підприємства 
погашати свої зобов'язання. Такий рівень можливо досягнути застосовуючи традиційний чи функціональний підходи до фінансування.

Характеризуючи традиційний підхід до фінансування варто зазначити, що він спирається на виконання таких правил:

1) правило мінімальної фінансової переваги - наявність обов'язкової позитивної ліквідності, що визначається шляхом формування відповідного резерву забезпечення платоспроможності, який можливо використовувати для покриття можливого ризику виникнення невідповідності в обсязі, періоді та швидкості обороту короткострокових активів та пасивів балансу. В якості такого резерву можливо використовувати робочий капітал підприємства, що характеризується перевищенням поточних активів над поточними зобов'язаннями;

2) правило максимальної заборгованості визначає, що довго- та середньострокові зобов'язання не повинні перевищувати половини постійного капіталу підприємства, який включає власний капітал і прирівняні до нього довгострокові джерела.

В свою чергу функціональний підхід включає в себе такі правила та вимоги як:

1) скориговане правило фінансової рівноваги - власний і прирівняні до нього капітал повинні повністю покривати стабільно розміщені активи (необоротні активи), тобто резерв ліквідності оцінюється за величиною власних оборотних коштів;

2) обсяг потреби в оборотних коштах (власних оборотних коштах) змінюється протягом всього звітного періоду. Такі зміни призводять, з одного боку, до надлишкового обсягу оборотних активів при якому частина коштів вивільняється, тобто з'являються вільні джерела власних оборотних коштів, а з іншого боку до незадоволення потреби в оборотних коштах, що призводить до залучення позикових ресурсів;

3) питома вага короткострокових зобов'язань у складі джерел фінансування не може перевищувати частку ліквідних активів (грошові кошти і фінансові інвестиції, поточна дебіторська заборгованість і запаси, призначені для продажу). Решта активів повинна бути профінансована за рахунок власного капіталу або довгострокових зобов'язань. 3 врахуванням цього, необхідна (достатня) частка власного капіталу у складі джерел фінансування $\epsilon$ вже індивідуальною для кожного підприємства і на кожну звітну дату.

Якщо мова йде про забезпечення необхідного приросту активів джерелами фінансування то найбільш сприятлива для підприємства складається ситуація, коли приріст нерозподіленого прибутку, амортизаційних відрахувань, інших власних джерел фінансування дорівнює приросту необоротних активів і необхідних запасів. Приріст решти елементів активів може бути забезпечений збільшенням поточних зобов'язань 
підприємства. Що стосується додаткового залучення короткострокових позикових коштів, то іiі доцільність визначається можливим приростом рентабельності власного капіталу.

Враховуючи підходи щодо фінансування активів підприємства за рахунок власних джерел формування капіталу та для забезпечення перспективної платоспроможності обсяги власних оборотних коштів підприємства повинні відповідати розміру робочого капіталу.

Водночас залучення позикового капіталу в оптимальних обсягах та ефективне їх використання також має значний вплив на платоспроможність підприємства. Пропорційне підвищення частки власного капіталу в загальній структурі капіталу призводить до підвищення ризику та зниження платоспроможності підприємства

На структуру джерел формування капіталу безпосередньо впливає тривалість обороту коштів. Підприємство у якого період обороту коштів менший може мати більшу частку позикового капіталу без загрози для власної платоспроможності. Також важливо зазначити, що чим менша частка постійних витрат у собівартості продукції підприємства, тим менший ризик втрати платоспроможності.

Ліквідність оборотних активів підприємства напряму поєднана 3 поточними пасивами, оскільки від їх узгодженості залежить формування та можливість нарощення чистого оборотного (робочого) капіталу. При цьому важливого значення набуває вибір оптимальної моделі фінансування оборотних активів.

Відомо, що в теорії фінансового менеджменту виділяють чотири моделі фінансування оборотних активів: ідеальну, агресивну, консервативну та компромісну.

Ідеальна модель полягає у тому, що довгострокові пасиви встановлюються на рівні необоротних активів, а короткострокові зобов'язання - оборотних активів. В таких умовах у підприємства відсутні як власні оборотні кошти, так і робочий капітал. У реальному житті ідеальна модель практично не застосовується через те, що вона є досить ризиковою, оскільки не передбачає формування резерву платоспроможності.

Агресивна модель фінансування оборотних активів полягає в тому, що довгострокові пасиви є джерелом покриття необоротних активів та постійної частини оборотних, тобто їх мінімуму, який необхідний для здійснення господарської діяльності, визначеного на основі нормування без врахування страхових запасів. У цьому разі змінна частина оборотних активів у повному обсязі забезпечує погашення короткострокових зобов'язань. Робочий капітал дорівнює постійній частині оборотних активів.

3 позиції ліквідності і поточної платоспроможності ця стратегія також $є$ ризикованою, оскільки обмежуватися лише мінімумом поточних активів 
досить складно. Таку стратегію фінансування оборотних активів може дозволити собі підприємство, яке не має проблем 3 отриманням короткострокових кредитів або комерційних кредитів постачальників. Крім того, агресивна політика здатна знизити ризик неплатоспроможності, але не може забезпечити високої рентабельності активів.

Консервативна модель фінансування оборотних активів передбачає, що змінна частина поточних активів також покривається довгостроковими пасивами. Як правило, така модель застосовується на початкових стадіях діяльності підприємства за умови достатньої величини капіталу власників підприємства i доступності довгострокових кредитів для фінансування. Запорукою високого рівня платоспроможності $є$ відсутність у підприємства короткострокової заборгованості.

Компромісна модель фінансування оборотних активів найбільш реальна. Сутність її полягає в тому, що необоротні активи, постійна частина оборотних активів і приблизно 0,5 змінної частини поточних активів покриваються довгостроковими пасивами. При цьому робочий капітал визначається як різниця між довгостроковими пасивами і необоротними активами. Зауважимо,

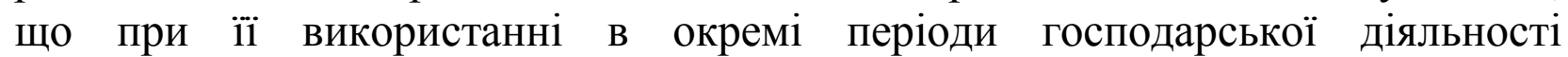
підприємство може мати надмірний обсяг оборотних активів, що негативно впливає на розмір прибутку [14].

Отже, вибираючи стратегію фінансування оборотних активів, варто орієнтуватися на бажане співвідношення між рівнем рентабельності та рівнем ризику втрати платоспроможності підприємства, яке оцінюється необхідною величиною робочого капіталу. Характер заходів, що спрямований на досягнення цільового рівня платоспроможності залежить від того, який 3 показників фінансового стану у підприємства має незадовільне значення.

Наступною важливою запорукою забезпечення платоспроможності підприємства $є$ уміння планомірно та раціонально керувати кредиторською та дебіторською заборгованістю. Така умова полягає у регулярному моніторингу за обсягом та співвідношенням дебіторської та кредиторської заборгованості, показниками їх оборотності і періодом погашення.

Управління кредиторською та дебіторською заборгованістю ототожнюють з управлінням оборотними активами та джерелами оборотних коштів, які $\epsilon$ вкрай важливими для забезпечення платоспроможності підприємства.

Взагалі дебіторська заборгованість є оборотними активами, які вилучені на певний момент, саме тому, чим швидше підприємство отримає кошти за надані товари, роботи та послуги, тим кращим є його фінансовий стан. Саме зростання вартості дебіторської заборгованості свідчить про надання підприємством позик у товарній формі своїм споживачам. Взагалі величина дебіторської заборгованості залежить від обсягів продажу, умов розрахунку 3 
покупцями, періоду відстрочки платежу, платіжної дисципліни покупців, організації контролю за станом розрахунків $з$ дебіторами, претензійної роботи на підприємстві.

Як правило зменшення обсягів дебіторської заборгованості розцінюється позитивно, але якщо дебіторська заборгованість зменшується за рахунок скорочення обсягів відвантаженої продукції, то це призводить до зниження ділової активності підприємства. Також бажано, щоб структура дебіторської заборгованості не містила простроченої, безнадійної, віднесеної до резерву сумнівних боргів заборгованості. У разі виникнення таких статей варто провести аналіз дебіторської заборгованості в позиції строків неплатежу. Суть даного дослідження полягає у градації заборгованості відповідно за строками (до 3 місяців, від 3 до 6 місяців, від 6 до 12 місяців), порівнянні ії в динаміці та визначенні причин збільшення тривалості перебування коштів у дебіторській заборгованості.

Якість дебіторської заборгованості варто оцінювати через показники оборотності, які характеризують швидкість та час ії повернення. Підвищення вказаних коефіцієнтів можливо за рахунок аналізу фінансового стану потенційних дебіторів та їх платоспроможність, репутації, термінів існування, кон'юнктурної стадії в галузі, де партнери здійснюють свою діяльність; диверсифікації клієнтури; визначення максимальної суми боргу в цілому та на одного клієнта (лімітування дебіторської заборгованості); використання різних форм забезпечення повернення боргу (застава, страхування, гарантії банків або третіх осіб, оформлення забезпеченим векселем тощо); підвищення дієвості штрафних санкцій щодо боржників.

В процесі роботи 3 дебіторами варто прискорити розрахунки 3 ними використовуючи різноманітні форми рефінансування, або іншими словами переведення дебіторської заборгованості в інші ліквідні форми оборотних активів. Така процедура надасть можливість збільшити суму ліквідних активів. Основними формами рефінансування визначено: факторинг, форфейтинг, облік векселів, спонтанне фінансування та інші. Всі вони базуються на тому, що витрати, які спрямовані на рефінансування не повинні перевищувати очікуваний прибуток від використання вивільнених коштів, збільшувати вартість короткострокових кредитів для підтримки платоспроможності та інфляційних витрат, що виникають у випадку затримки платежів.

Поряд 3 дебіторською заборгованістю підприємства варто розглядати і кредиторську, яка інтерпретується як залучення деякої частики оборотних коштів у господарську діяльності. Знову ж таки в процесі дослідження кредиторської заборгованості 3 позиції платоспроможності звертають увагу на склад, структуру, якість та співвідношення іiі 3 дебіторською заборгованістю. 
Якщо вартість кредиторської заборгованості зростає і при цьому темп іiі приросту менший від темпів приросту оборотних активів (особливо високоліквідних) то це свідчить про підвищення рівня платоспроможності підприємства. Також позитивною характеристикою вважається скорочення в динаміці суми кредиторської заборгованості за видами та в цілому, зниження iii частки у джерелах формування капіталу та зобов'язаннях.

Успішне управління кредиторською заборгованістю постійно пов'язане 3 контролем за співвідношенням дебіторської та кредиторської заборгованості та моніторингом стану розрахунків за простроченою заборгованістю.

Вважають, що ідеальним для будь-якого підприємства $\epsilon$ таке співвідношення коли кредиторська заборгованість перевищує дебіторську на 10-20\%. Але як показують досліджень на деяких підприємствах кредиторська заборгованість перевищує дебіторську в десятки разів. При цьому варто зазначити, що значні обсяги дебіторської заборгованості можуть бути ознаками раннього банкрутства. 3 огляду на такі обставини, підприємству варто контролювати інформацію про стан рахунків 3 дебіторами та кредиторами так як вони $€$ індикаторами потенційних загроз погіршення його фінансової безпеки.

Підвищення швидкості оборотності дебіторської заборгованості порівняно 3 кредиторською дає змогу підприємству отримувати грошові ресурси від дебіторів та спрямовувати їх на погашення боргів кредиторам. Таким чином протягом певного періоду у розпорядженні підприємства знаходяться вільні кошти, які можливо вкладати в прибуткові активи. Такий вектор поведінки підприємства свідчить про його виважену кредитну політику. Ознаками нераціональної кредитної політики $є$ збільшення обсягів дебіторської заборгованості. В такому разі необхідно звернути увагу на умови надання кредиту під час реалізації, строк та гарантії, що надаються під кредит.

Вважаємо, що перевищення кредиторської заборгованості над дебіторською з одного боку може трактуватися як раціональне використання фінансових ресурсів, оскільки підприємство залучає у господарську діяльність більше коштів, ніж відволікає в оборот, а $з$ іншого - підприємство змушене повертати свої зобов'язання перед кредиторами не залежно від стану дебіторської заборгованості.

Забезпечення та управління платоспроможністю підприємства значною мірою залежить від раціонального та збалансованого управління грошовими потоками. Основними засадами такого управління визначено:1) забезпечення мінімального необхідного обсягу грошових ресурсів для постійного проведення поточних розрахунків; 2) постійний моніторинг за вхідними та вихідними грошовими потоками, а також за сезонними змінами залишку грошових коштів; 3) формування резерву тимчасово вільних грошових коштів, які можливо спрямувати на розширення діяльності підприємства; 4) 
оптимізація системи розрахунків із постачальниками і покупцями, тобто обгрунтування політики надання комерційних кредитів i отримання відстрочки платежів; 5) мобілізація резервів грошових ресурсів для відшкодування непередбачених витрат та можливих втрат в процесі фінансово-господарської діяльності; 6) трансформація вільних грошових коштів у високоліквідні активи, а також зворотна їх конвертація для поповнення залишку грошових коштів [8].

Сутність забезпечення грошових потоків полягає в збалансованості позитивних та негативних грошових потоків у часі та за центрами відповідальності. Дефіцит грошового потоку породжує зниження ліквідності активів та рівня платоспроможності підприємства, зростання обсягів кредиторської заборгованості та виникнення затримок платежів за кредитним ресурсам. Надлишковий грошовий потік характеризується уповільненням оборотності капіталу, втратою реальної вартості тимчасово вивільнених коштів та частини потенційного доходу, який пов'язаний з розміщенням коштів в операційному та інвестиційному процесах.

Досягнення збалансованості дефіцитного грошового потоків у короткостроковій перспективі напряму пов'язане 3 системою заходів, які спрямовані на прискорення залучення коштів та на уповільнення видатків. До основних заходів щодо прискорення залучення коштів варто віднести рефінансування дебіторської заборгованості, застосування цінових знижок на продукцію реалізовану за готівкові кошти, скорочення строків кредиту, та застосування механізму передоплати за розрахунками. Уповільнення видатків можливе за рахунок трансформації короткострокових кредитів у довгострокові, зростання строків кредитів, використання лізингу. Застосування вищенаведених заходів сприятимуть підвищенню рівня платоспроможності підприємства в короткостроковому періоді, але також можуть призвести i до виникнення дефіцитного грошового потоку в майбутньому.

В якості оптимізації грошових потоків в часі використовують їх вирівнювання та синхронізацію. Вирівнювання полягає в згладжуванні обсягів грошових потоків за окремими часовими інтервалами і як наслідок зниження коефіцієнта коваріації. Синхронізація вказує на спроможність підприємства генерувати грошові потоки від операційної, інвестиційної та фінансової діяльності. Основним бажаним результатом такого методу оптимізації $є$ те, щоб у кожний момент часу чистий грошовий потік повинен бути позитивним.

Досліджуючи забезпеченість платоспроможності з позиції синхронізації формування грошових потоків розраховують коефіцієнт ліквідності грошового потоку підприємства. Він слугує для оцінювання можливих обсягів окремих джерел надходження та використання грошових потоків, визначення прогнозного рівня платоспроможності підприємства на основі динамічної 
тенденції. Для забезпечення необхідної ліквідності значення даного коефіцієнта має бути не нижчим від 1 [13, с. 278].

Останнім етапом в процесі оптимізації грошових коштів підприємства $\epsilon$ максимізація чистого грошового потоку, яка забезпечує підвищення рівня самофінансування та зниження залежності від зовнішніх джерел фінансування.

Оскільки платоспроможність визначають як здатність підприємства сплачувати кошти за зобов'язаннями, що настали і потребують термінового погашення, необхідно об'єктивно підходити до планування грошових потоків. Вважаємо, що у підприємства має бути залишок грошових коштів, який дорівнює різниці між кредиторською заборгованістю всіх видів, строки сплати якої настають найближчим часом, i поточною дебіторською заборгованістю на користь підприємства, платежі за якою очікуються у той самий час.

В умовах коли підприємство прагне до економії витрат на оплату коштів та страхування ризиків від факту несплати за поставлену продукцію, товар чи послугу актуальним постає питання вибору та застосування різноманітних форм ефективних розрахунків. В основу їх ефективності покладено ряд критеріїв, які також $є$ важелями управління платоспроможністю підприємства в контексті фінансової безпеки.

Важливим в процесі проведення розрахунків $є$ фактор порівняння часу, який необхідний для одержання відповідного платежу 3 тривалістю виробничого процесу. Крім того ефективність форм розрахунків напряму залежить від швидкості зарахування коштів на рахунок постачальника [10 c. 60]. Зміна структури розрахунків підприємства напряму впливає на швидкість обороту товарно-матеріальних цінностей та на оборотність коштів в його розрахунках з партнерами. Таке прискорення можливо забезпечити за рахунок максимального зближення строків оплати товару та їх надходження до покупців та за рахунок використання найбільш раціональних форм розрахунків.

Змінюючи форму розрахунків логічно змінюється і час між оплатою продукції та іiі надходженням до покупців. Іншими словами така ситуація призводить до коливання обсягів товарно-матеріальних запасів, дебіторської та кредиторської заборгованості, величина яких відповідає структурі розрахунків. Враховуючи такі умови визначено, що у разі заміщення однієї форми розрахунку на іншу змінюються і статті балансу. А як відомо зміна статей звіту про фінансовий стан підприємства призводить до зміни фінансових показників його діяльності. Спираючись на окреслені умови підприємство може використовувати ряд сучасних різноманітних форм розрахунків до яких можливо віднести авансову форму розрахунків, інкасо, банківський переказ, акредитив та інші. 
Отже, вважаємо, що прискорення обороту розрахунків залежить від ефективності і швидкості руху продукції від постачальника до покупця, а також від швидкості перерахування коштів із рахунку платника на рахунок одержувача коштів. Ці величини і можна визначити як основні критерії ефективності форм розрахунків. Таким чином, платоспроможність підприємства напряму залежить від рівня ефективності використання тієї чи іншої форми безготівкових розрахунків.

Висновки. Таким чином, визначення підходів щодо дослідження фінансової безпеки підприємства 3 точки зору уникнення загрози неплатоспроможності підтверджує потребу вибору оптимальних умов забезпечення платоспроможності виробничо-економічних систем, які впливають на ефективність ведення їх фінансово-господарської діяльності. Це дозволило запропонувати власне бачення основних умов забезпечення платоспроможності підприємства. Такими умовами визначено: наявність та забезпечення ліквідності активів та задовільної структури балансу; збалансована структура джерел формування капіталу підприємства; ефективне управління дебіторською та кредиторською заборгованістю; раціональне та збалансоване управління грошовими потоками; вибір та застосування ефективних форм розрахунків.

На основі отриманих результатів доведено, що вищевикладенні умови забезпечення платоспроможності мінімізують ризик загрози погіршення рівня фінансової безпеки підприємства. Тому, для подальшого дослідження, у цьому напрямку необхідно зосередити свою увагу на механізмі забезпечення платоспроможності в точки зору зміцнення фінансової безпеки підприємства.

\section{Література:}

1.Бланк И. А. Основы финансового менеджмента / И. А. Бланк. - К.: Ника-Центр, 1999. - T. 1. $-590 \mathrm{c}$.

2.Галасюк В. В. Об определении понятия «платежеспособность» в контексте концепции CCF / В. В. Галасюк // Фондовый рынок. - 2003. - № 13. - С. 26-33.

3.Журавльова Ю. Ю. Платоспроможність підприємства та шляхи ії забезпечення (на прикладі харчової промисловості): автореф. дис. на здобуття наук. ступеня канд. екон. наук: спец. 08.00.08 «Гроші, фінанси і кредит» / Ю. Ю. Журавльова. - К., 2007. - 20 с.

4.Журавльова Ю. Ю. Сутність платоспроможності підприємства / Ю. Ю. Журавльова // Фінанси України. - 2006. - № 2. - С. 116-120.

5.Іванов В. Концептуальні засади забезпечення платоспроможності підприємства / В Іванов // Економіка. - 2009. - №9 (100). - С.4-8.

6. Іонін Є. Є. Розв'язання питань методологічного обгрунтування понять «платоспроможність» і «ліквідність» / Є. Є. Іонін // Актуальні проблеми економіки. - 2009. - № 6. - С.30-42.

7. Коваленко Л. О. Фінансовий менеджмент: Навч. Посіб. / Л. О. Коваленко, Л. М. Ремньова. - 2-ге вид., перероб. і доп. - К.: Знання, 2005. - 485 с.

8. Крамаренко Г.О. Фінансовий менеджмент. [підручник] / Г.О. Крамаренко - К.: ЦУЛ, 2006. - 520 с. 
9. Міжнародні комерційні угоди та розрахунки: нормативно-правове регламентування: Навч. посіб. для студ. вищ. навч. закл. / за ред. Ю. Г. Козака, Н. С. Логвінової; М-во освіти і науки України. - К.: Центр учбової літератури, 2010. $648 \mathrm{c}$.

10. Рибченко М. Ф. Оптимізація системи безготівкових розрахунків / М. Ф. Рибченко // Фінанси України. - 2012. - № 13 (86). - С. 58-64

11. Солодухин Д. Н. Финансовая стратегия восстановления платежеспособности предприятия / Д. Н. Солодухин //Финансы. - 2008. - № 4. - С. 65-67.

12. Солотва В. Сутність платоспроможності підприємства / В. Солотва // Фінанси України. - 2010. - №1. - С. 116-120

13. Тютюнник Ю. М. Фінансовий аналіз: Навч. посіб. / Ю. М. Тютюнник. - К.: Знання, 2012. $-816 \mathrm{c}$.

14. Фінанси підприємств / А. М. Поддєрьогін, М. Д. Білик,Л. Д. Буряк та ін.; за заг. ред. А. М. Поддєрьогіна. - 7-ме вид. - К.: КНЕУ, 2008. - 552 с.

15. Шеремет А. Д. Методика финансового анализа / А. Д. Шеремет, Р. С. Сайфулин. М.: Инфра-М, 2008. - 208 с.

16. Якобець Х. Г. Вплив різних форм безготівкових розрахунків на фінансовий стан підприємства / X. Г. Якобець [Електронний ресурс]. - Режим доступу: http://intkonf.org/yakobets-hg-vpliv-riznih-form-bezgotivkovih-rozrahunkiv-na-finansoviy-stanpidpriemstva/ 